пласт концептуальных суждений относительно роли морального фактора в деятельности сотрудников органов внутренних дел.

1. Паскаль О. Полиция - это общество, а общество - это полиция. - URL: https://www.openrussia.org/notes/709952 (дата обращения: 12.11.2020).

2. Чимаров С.Ю. К вопросу о «принципах правоприменения» Роберта Пиля в деятельности полиции // Вестник Санкт-Петербургского университета МВД России. - 2017. - № 3 (75). - С. 33-34.

3. Beauchamp T.L., Childress J.F. Principles of Biomedical Ethics. - New York: Oxford University Press, 1979. $-512 \mathrm{p}$.

4. Gillon R. The Principles of Health Care Ethics. - Lincoln: Collections curated by Anybook Ltd, 1999.URL: https://www.abebooks.co.uk/ (дата обращения: 20.11.2020)

5. Lindridge J. Principlism: when values conflict // Journal of Paramedic Practice. - 2017. - Vol. 9 (4). - P. 158-163.

6. The Belmont Report Ethical Principles and Guidelines for the Protection of Human Subjects of Research. - Washington: The National Commission for the Protection of Human Subjects of Biomedical and Behavioral Research, 1978. -20 p.

\title{
Galushcinskaya Y.O., Yurovskih N.S. \\ Use in learning students in the distance format of innovations in order to preserve learning motivation
}

Federal State Budgetary Educational Institution of Higher Education «Shadrinsk State Pedagogical University» (Russia, Shadrinsk)

doi: $10.18411 / \mathrm{lj}-12-2020-167$

idsp: ljournal-12-2020-167

\section{Аннотация}

В статье раскрывается использование преподавателями при обучении в дистанционном формате различного рода инноваций в целях сохранения учебной мотивации и развития научной, творческой и инновационной деятельности молодежи.

Ключевые слова: дистанционное обучение, инновации в обучении, активные и интерактивные формы обучения.

\section{Abstract}

The article reveals the use of various types of innovations by teachers in distance learning in order to preserve educational motivation and develop scientific, creative and innovative activities of young people. learning.

Keywords: distance learning, innovations in learning, active and interactive forms of

\section{Introduction.}

The situation with countering Covid-19 was the reason for the transfer of students and teachers of the country's higher educational institutions to distance learning from March-April 2020.

Within the framework of training in higher educational institutions, this form of training involves the conduct of lecture and seminar-type classes, as well as the delivery of various types of intermediate certification, exams and tests, in the online format. Naturally, such an innovative form of organization of the educational process for Russian education is widely covered and discussed in the media, and researched by scientists.

Analysis of the preparation of educational institutions for teaching students in a distance format. 
For example, a joint research study was conducted by the National Research University Higher School of Economics and Tomsk State University on the specifics of online student learning during the coronavirus pandemic.

The study was conducted in two stages (from 03.24. .2020 to 01.06.2010) with the participation of 35 thousand students from about 400 higher educational institutions in Russia.

The results of the study showed that its participants highly appreciated the readiness of educational institutions for an emergency transition to distance learning [5].

The positive nature of the assessment was influenced, according to the researchers, by the creation in higher educational institutions of the Russian Federation, during the 2017-2018 academic year, of an electronic information and educational environment, with an existing link on the websites of educational institutions.

This system has been created in higher educational institutions of the Kurgan region.

For example, in the electronic information and educational environment of the federal state budgetary educational institution of higher education «Shadrinsk State Pedagogical University» there are references to:

— «educational programs»;

— implemented «areas of training».

In addition, we can say that:

- all disciplines taught to students are formalized and content-rich;

- feedback from students is organized;

— all students have access to subjects in their field of study;

- the training and computing center issues logins and passwords to all participants in the educational process of the university.

In the electronic information and educational environment of the federal state budgetary educational institution of higher education, the Kurgan State Agricultural Academy named after T.S. Maltsev:

- access to curricula, work programs, electronic library systems and educational resources is provided;

- the course of the educational process and the interaction between its participants are recorded;

- reflects the results of intermediate certification, the results of mastering the basic educational program of an educational institution.

Analysis of the negative aspects of distance learning.

Conducted express research with students showed that they have problems associated with the organization of distance learning and leading to a decrease in its effectiveness.

These include:

1) problems of a moral and psychological nature. For example:

- personal discomfort, lack or complete lack of personal communication with other students;

- the complexity of learning at home, fatigue in the process of being at the computer online for more than 6 hours of work, and so on;

2) problems of a subjective nature.

- For example: a teacher mistakenly uploads the text of a lecture or assignments for seminars in the block of the studied subject in the electronic information and educational environment. However, he does not do so in a designated area. This makes it difficult to find them and complete assignments.

- Or, for example, failures in the organization of feedback. Here we are talking about the fact that grades in points, comments or reviews to the given grade may not be prescribed by the teacher. Therefore, students are not always 
timely informed about receiving a grade in a discipline, about the reasons for its decline or increase.

- And also the following problem can be named. The teacher assigns tasks for lectures and seminars with a higher level of complexity that does not correspond to the course of study in the main educational program of an educational institution. Also, the time to complete the task may be limited;

3) problems of an objective nature.

- For example, the impossibility of using interactive forms of education for technical reasons.

This can be:

- poor quality of the Internet connection and technical support of the participants in the educational process;

— using the platform «Zoom» and others for other purposes;

- the lack of platforms in the electronic information and educational environment of educational institutions that allow conducting classes online in the form of videoconferences;

- lack of mastery by the participants of the educational process of interactive forms of learning;

- and so on.

In this way, there are problems of organizing technical work in the electronic information and educational environment of educational institutions of various kinds.

The complex structure of the educational process leaves an imprint on the quality of scientific knowledge, reduces the motivation for the activities of the participants in the educational process - teachers and students.

Possibilities of using innovations in the process of distance learning.

We are considering the potential of educational institutions in the field of distance learning in order to preserve educational motivation and develop diversified cognitive activities of students.

In our opinion, to increase the effectiveness of distance learning, teachers not only use innovation, but also combine active and interactive teaching methods.

In the theory of education, innovative pedagogical technologies are widely described.

So E.V. Ivanova, L.I. Kosova describes them as a «system of methods» structured in the form of active and interactive teaching methods. Scientists point out that the strategy of interactive learning includes parity, multilateral communication, self-assessment, feedback, the condition of the activity of the teacher and the student $[2,52]$.

Yu.I. Ovchinnikova, M.V. Karpova, D.N. Ovchinnikov, N.V. Roznina reveal the importance of the role of interactive methods in teaching young professionals [3, 147].

Yu.I. Ovchinnikov and D.N. Ovchinnikov propose:

1) to use various innovations in teaching in conjunction with traditional forms in order to create creative and democratic conditions for overcoming the indifference and indifference of the student in the educational process.

They refer to innovative technologies in this case:

- dialogue method,

- methods of problem situations,

— simulation of practical situations,

- factor analysis when using multimedia tools;

2) apply problem statement and technologies of full-fledged cooperation during online classes $[4,66]$.

M.L. Almazova, M.V. Sozinova, I.M. Shestakov: 
1) propose to increase interest in the study of the discipline they teach. To do this, use interactive forms of learning in the classroom: role-playing games, case studies. This will increase the efficiency of independent work, self-control, mutual control;

2) note the possibility of using the learned concepts in the study of natural sciences and other disciplines [1, 479].

\section{Conclusion.}

We believe that the use of various innovations by teachers in distance learning, including active and interactive methods, is necessary in order to increase the effectiveness of the development of the intellectual potential of student youth, to preserve its cognitive motivation in the learning process.

$$
\text { *** }
$$

1. Almazova M.L., Sozinova M.V., Shestakova I.M. The use of active forms of education in practical classes // Scientific and innovative technologies as a factor of sustainable development of the agrarianindustrial complex: a collection of articles based on the materials of the All-Russian (national) scientific and practical conference / edited by I.N. Mikolajczyk. 2020. - S. 478-482.

2. Innovative pedagogical technologies // methodological guide for teachers of vocational schools / edited by E.V. Ivanova, L.I. Kosova, T.Yu. Avetova. - St. Petersburg: LLC «Polygraph - S», 2014. - 160 p.

3. Ovchinnikova Yu.I., Karpova MV, Ovchinnikov DN, Roznina NV. The role of interactive methods in teaching young specialists // Modern approaches to training personnel for the agro-industrial complex: collection of materials of the All-Russian educational and methodological conference. - Kurgan: Publishing house of the Kurgan State Agricultural Academy, 2017. - S. 146-149.

4. Ovchinnikova Yu.I., Ovchinnikov D.N. Innovations in teaching young specialists // Ensuring the quality of training students in basic educational programs taking into account the updated Federal State Educational Standards of Higher Education $(3++)$ and Federal State Educational Standards of Secondary Vocational Education for 50 of the most promising and demanded professions and specialties: a collection of articles on materials of the All-Russian (national) scientific and methodological conference / edited by Sukhanova S.F. - Kurgan: Publishing House of the Kurgan State Agricultural Academy, 2018 . - S. 64-68.

5. Students named the main problems of online learning [electronic resource] - URL: https://www.rbc.ru/society/19/08/2020/5f3bbdae9a7947d167de1a41 (date of treatment 10/30/2020). 